\title{
Enhanced antimicrobial activity of as synthesized nanoparticles using natural antioxidants of plants origin
}

\author{
Tamanna Malik* and V. K. Madan* \\ Department of Chemistry, College of Basic Sciences and Humanities, CCSHAU Hissar, Hissar-125004, Haryana, India \\ *MAP Section, Department of Genetics and Plant Breeding, CCSHAU Hissar, Hissar-125004, Haryana, India
}

\section{Article Info}

Article history

Received 11 April 2020

Revised 1 June 2020

Accepted 3 June 2020

Published online 30 June 2020

Keywords

Antibiotics

Antimicrobial

Nanoparticles

Bimetallic

Plant extracts

\begin{abstract}
To promote a healthy and disease free life, the Mother Nature has gifted mankind medicinal plants. A large number of medicinal plants used in a collection of herbal preparations of the Indian traditional health care system (Ayurveda) named Rasayana, are suggested for their interesting antioxidant and antimicrobial activities. Triphala is an Indian and Thai traditional herbal formulation composed of Emblica officinalis Gaertn., Terminalia belerica Roxb. and Terminalia chebula Retz.. Amongst these natural therapeutic agents, Amla showed the highest antibacterial activity followed by Triphala powder, Bahera and Harad. In case of Antifungal activity, it was Bahera which showed the highest activity against the available test organisms followed by Amla, Harad and Triphala powder. Phyto-synthesized metallic nanoparticles have many applications such as antimicrobial, biomedical, agriculture, bio-insecticides, catalyst, biosensor, etc. The antibacterial activities were inversely proportional to the average nanoparticle sizes. Bimetallic nanoparticles possessed better antimicrobial activity as compared to monometallic nanoparticles. Gram negative (Escherichia coli and Pseudomonas aeruginosa) bacteria were more susceptible to gram positive (Staphylococcus aureus and Bacillus subtilis) bacteria. The order for antibacterial efficacies is as follows:

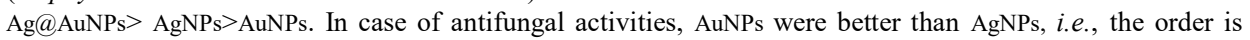
Ag@AuNPs $>$ AuNPs $>$ AgNPs. Aspergillus niger was most susceptible fungal organism as compared to Aspergillus flavus and Candida albicans to the action of these plant derived therapeutic agents. The use of these compounds as therapeutic agents will open a chapter of cheaper and safe herbal substitute of antibiotics and may prove as a tool to check the problem of increasing antimicrobial resistance in pathogens.
\end{abstract}

\section{Introduction}

Infectious diseases are a serious reason of morbidity and mortality globally. It accounts for roughly $50 \%$ of all deaths in tropical countries and the maximum amount as $20 \%$ of deaths within the America (Bhandari and Kamdod, 2012). Notwithstanding the noteworthy advancement made in microbiology additionally to the control of microorganisms, intermittent occurrences of epidemics because of drug resistant microorganisms and previously unknown disease causing microbes pose an enormous risk to public health. These adverse health developments demand a universal initiative for the advancement of novel approaches for the prevention and treatment of these diseases.

For over 100 years, chemical compounds which are isolated from medicinal plants along with some modifications can be served as the models for a number of clinically proven drugs, and are now being re assesed as antimicrobial agents. The reasons for this revival include a decrement in the new antibacterial drugs within the pharmaceutical pipeline, a proliferation in antimicrobial resistance, and therefore, the necessity of treatments for new growing pathogens. Factually,

Corresponding author: Ms. Tamanna Malik

Department of Chemistry, College of Basic Sciences and Humanities, CCSHAU Hissar, Hissar-125004, Haryana, India

E-mail: maliktamanna1996@gmail.com

Tel.: +91-9717652057

Copyright $@ 2020$ Ukaaz Publications. All rights reserved.

Email: ukaaz@yahoo.com; Website: www.ukaazpublications.com thousands of plant species had been tried against a number of bacterial strains in vitro and lots of medicinal plants are active against a wide range of gram positive as well as gram negative bacteria (Mahady, 2005). Antimicrobial assay is to work out in terms of measuring zone of inhibition $(\mathrm{mm})$, where larger the zone of inhibition indicates the greater antimicrobial activity. Plant-derived drugs have a crucial place in both traditional and modern medicine. Medicinal plants comprise the base of health care systems in numerous societies. These are important source for finding new antimicrobial agents with significant activity against infective microbes. Drugs isolated from the plants are easily available, inexpensive, safe, efficient and with fewer side effects. Today's, microbial infections, resistance to antibiotic drugs, have been the major challenges, which menace the health of societies. Microbial infections are liable for millions of deaths per annum worldwide. In 2013, 9.2 million deaths are reported due to infections, i.e., about $17 \%$ of total deaths. The two mechanisms mainly ascribed to the antibacterial activity of an agent may include intervening chemically with the synthesis or function of vital components of bacteria, and/or evading the usual mechanisms of antibacterial resistance (Khameneh et al., 2019).

In addition, bacteria may show resistance to antibacterial agents through a number of mechanisms. Some bacterial species are inherently resistant to one or more classes of antimicrobial agents. A serious concern is that the bacteria acquire resistance, where initially susceptible bacterial populations become resistant to the antibacterial agent. 
Green synthesis of metallic NPs by using plant extracts gained significant interest over the years due to the remarkable antibacterial and anticancer properties of these nanoparticles. The excellent antibacterial activity and anticancer activity of metallic nanoparticles are mainly attributed to their high surface area-to-volume ratio which enables greater presence of atoms on the surface and, in turn, greater contact with the environment.

Herein, we have compared the antimicrobial activity of as synthesized metallic/bimetallic nanoparticles using plant derived antioxidants or secondary plant metabolites by measuring the zones of inhibition (ZOI) recorded for the doses of $10 \mathrm{mg}, 20 \mathrm{mg}, 30 \mathrm{mg}$ and $40 \mathrm{mg}$ against each isolates for $48 \mathrm{~h}$ along with the crude plant extracts of Amla, Bahera, Harad and Triphala powder. The antibiotic, Gentamycin was taken as a reference or control for the experiment.

\section{Materials and Methods}

\subsection{Synthesis of metallic/bimetallic nanoparticles}

The required chemicals, silver nitrate $\left(\mathrm{AgNO}_{3}\right)$ and chloroauric acid $\left(\mathrm{HAuCl}_{4} \cdot \mathrm{xH}_{2} \mathrm{O}\right)$ were purchased from Sigma Aldrich, India. $1 \mathrm{mM}$ $\mathrm{AgNO}_{3}$ and $1 \mathrm{mM} \mathrm{HAuCl} 4 . \mathrm{xH}_{2} \mathrm{O}$ solution was prepared. In a typical synthesis for silver and gold nanoparticles using plant extract, the extract was taken in a burette and the precursor solutions were kept on a heating stirrer with $450 \mathrm{rpm}$ at a varying temperature range of $60-80^{\circ} \mathrm{C}$ in dark. While synthesizing AgAuNPs, equimolar solution of $\mathrm{AgNO}_{3}$ and $\mathrm{HAuCl}_{4} \cdot \mathrm{xH}_{2} \mathrm{O}$ was used as the starting precursor for the synthesis of $\mathrm{Ag} @ \mathrm{Au}$ bimetallic nanoparticles. After the completion of synthesis of nanoparticles, the resulting solution is centrifuged at $8000 \mathrm{rpm}$ for $25 \mathrm{~min}$. The remaining solution (supernatant) was discarded with the help of pipette and the sediment is washed repeatedly with distilled water several times and finally with absolute ethanol. The sediment is dried in the oven at $60^{\circ} \mathrm{C}$ for $4 \mathrm{~h}$. The synthesized nanoparticles were then collected in the sample vial and correctly labeled. These were stored in freeze drying conditions till their characterization and further use/testing their antimicrobial activity against the available pathogens.

2.2 Estimation of the antimicrobial activity of as synthesized nanoparticles and crude extracts of triphala powder and its fruit constituents: Amla, bahera and harad

The antimicrobial activity was tested against the human pathogens (bacteria/fungi) using aqueous extract of E. officinalis (Amla), T. belerica (Bahera), T. chebula (Harad) and Triphala powder and as synthesized nanoparticles by standard protocol.

2.2.1 Preparation of test solutions for antimicrobial activity

The minimum amount of Dimethyl Sulfoxide (DMSO) was used in preparing a stock solution of $100 \mathrm{mg} / \mathrm{ml}$ of each extract and the volume is made up with distilled water. Further, dilutions of $10 \mathrm{mg} / \mathrm{ml}$, $20 \mathrm{mg} / \mathrm{ml}, 30 \mathrm{mg} / \mathrm{ml}$ and $40 \mathrm{mg} / \mathrm{ml}$ were made up from the stock solution for determining their antifungal and antibacterial activity.

\subsubsection{Antifungal activity}

\section{i. Test organisms}

Human pathogenic fungi, Candida albicans, Aspergillus flavus and $A$. niger were used for evaluating antifungal activity of the extracts of E. officinalis, T. belerica, T. chebula and Triphala powder as well as the synthesized nanoparticles (Ag, Au and Ag@Au) using these crude extracts. Test organisms were procured from the Department of Biochemistry, IIT Delhi.

\section{ii. Preparation of medium}

The most extensively used fungal media, Potato Dextrose Agar (PDA) consists of the following:

- Water $1000 \mathrm{ml}$

- Potatoes $250 \mathrm{~g}$

- Dextrose $20 \mathrm{~g}$

- Agar powder $20 \mathrm{~g}$

$250 \mathrm{~g}$ of washed and chopped potatoes in approx. 1 litre distilled water were boiled for $30 \mathrm{~min}$ in order to prepare Potato infusion and then strain the broth through muslin cloth. The total volume of the suspension was made 1 litre by Distilled Water. After the addition of $20 \mathrm{~g}$ dextrose and $20 \mathrm{~g}$ agar powder, the sterilization of the medium is done by autoclaving at $15 \mathrm{lbs}$ for $20 \mathrm{~min}$. In order to prevent the growth of unwanted bacteria, Gentamycin $(50 \mathrm{mg} / \mathrm{l})$ was also added as a control in order to compare the antibacterial activity among the test samples.

\section{iii. Test of antifungal activity}

Out of all the available methods, the most common poisoned food technique by Grooves and Moore (1962). Tuit (1969) was used for the assessment of antifungal activity. The test fungi were grown on PDA medium. The desired concentration/amount of extracts in $1 \mathrm{ml}$ of DMSO was subsumed aseptically into $99 \mathrm{ml}$ aliquots of sterilized PDA medium which was cooled at $45^{\circ} \mathrm{C}$. After pouring each lot of medium in Petri-dishes, these were allowed to solidify. DMSO (4 1ml) in the medium was taken as a control.

A $5 \mathrm{~mm}$ mycelial disc cut from the periphery of 2-3 days old fungal colonies were used for the inoculation of each dish at the centre. These inoculated Petri dishes were incubated in the dark at $25 \pm$ $2{ }^{\circ} \mathrm{C}$ for $48-72 \mathrm{~h}$ and colony diameters were measured periodically till the control dishes were nearly completely covered with fungus growth.

iv. Antibacterial activity

Test organisms

The bacterial cultures of two gram negative and two gram positive namely E. coli (ATCC 25922), P. aeruginosa (ATCC 27853) and S. aureus (ATCC 29213), B. subtilis (ATCC 6633) were used for evaluating the antibacterial activity of the extracts of $E$. officinalis, T. belerica, T. chebula and Triphala powder as well as the synthesized nanoparticles (Ag, $\mathrm{Au}$ and $\mathrm{Ag} @ \mathrm{Au}$ ) using these crude extracts. Test organisms were obtained from the Department of Biochemistry, IIT Delhi.

Preparation of medium

For the growth of bacteria, NA (Nutrient agar) medium is used which consists of the following:

\section{- Peptone $5 \mathrm{~g}$ \\ - Beef extract $3 \mathrm{~g}$ \\ - $\mathrm{NaCl} 5 \mathrm{~g}$ \\ - Agar-Agar $20 \mathrm{~g}$ \\ - Distilled water 1 litre}

All the constituents were dissolved in distilled water and the final volume was made to 1 litre.

Test of antibacterial activity

The Thornberry's method of zone inhibition was adopted for testing the extracts for their bactericidal activity. The bacterial suspensions 
were prepared using $48 \mathrm{~h}$ old culture. The bacterial growths from five slots were taken and mixed in $100 \mathrm{ml}$ sterilized distilled water aseptically.

The molten medium was cooled to $45^{\circ} \mathrm{C}$, and poured aseptically in sterilized Petri plates. For leveled distribution of the medium it was rotated gently and allowed to get solidified. Different concentrations of the test extracts $(10,20,30,40$ and $100 \mu \mathrm{g} / \mathrm{ml})$ were prepared from the stock solution by taking appropriate amount and the dilution is done using DMSO.
$10 \mathrm{~mm}$ diameter circular paper discs were prepared from Whatman's filter paper No. 1. The petri plates containing these discs were autoclaved at $15 \mathrm{lbs}$ pressure for $20 \mathrm{~min}$. One set for the control and two paper discs for each concentration of extract were used. These discs were soaked in different concentrations of the test compounds. The excess solution absorbed by the paper discs was removed by holding them vertically by sterile forceps. Such dipped discs were transferred aseptically to Petri plates containing bacterial suspension spread over the surface and media.

\section{Results}

Trends in antimicrobial activity

\begin{tabular}{|l|l|}
\hline Parameters & Order \\
\hline Antibacterial activity (Crude extracts) & Amla $>$ Triphala $>$ Bahera $>$ Harad \\
Antifungal activity (Crude extracts) & Bahera $>$ Amla $>$ Harad $>$ Triphala \\
Antibacterial activity (Biosynthesized NPs) & Ag@AuNPs $>$ AgNPs $>$ AuNPs \\
Antifungal activity (Biosynthesized NPs) & Ag@AuNPs $>$ AuNPs $>$ AgNPs \\
\hline
\end{tabular}

Table 1: Zone of inhibition ( $\mathrm{mm}$ ) by E. officinalis, T. belerica, T. chebula and Triphala at various concentrations towards different gram positive and gram negative bacteria

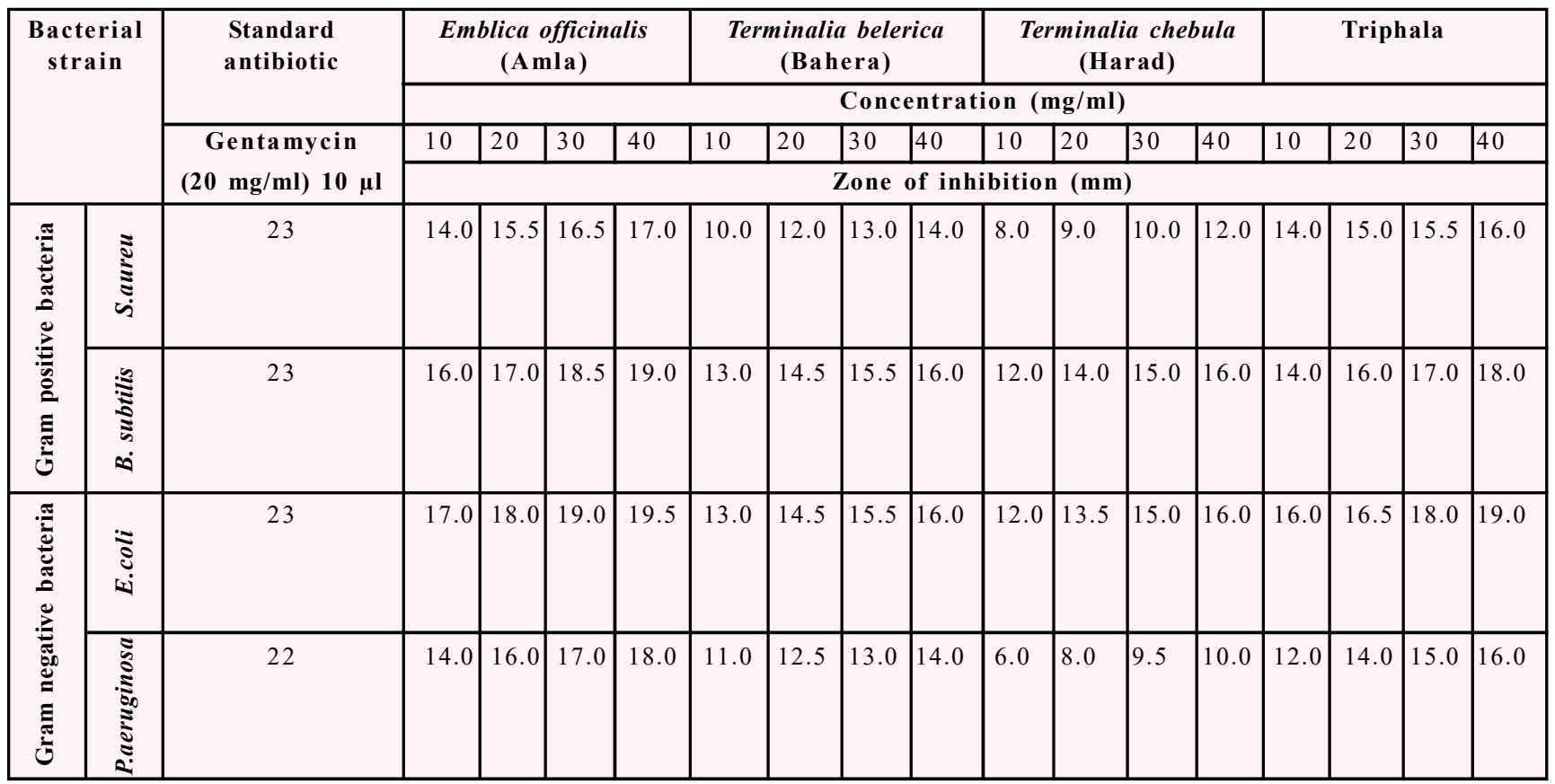

Table 2: Zone of inhibition ( $\mathrm{mm})$ by E. officinalis, T. belerica, T. chebula and Triphala at various concentrations towards different available strains of fungi

\begin{tabular}{|c|c|c|c|c|c|c|c|c|c|c|c|c|c|c|c|c|c|}
\hline \multirow[t]{4}{*}{$\begin{array}{l}\text { Bacterial } \\
\text { strain }\end{array}$} & \multirow[t]{2}{*}{ Standard } & & blica & $\begin{array}{l}\text { ffici } \\
\text { la) }\end{array}$ & & \multicolumn{4}{|c|}{$\begin{array}{c}\text { Terminalia belerica } \\
\text { (Bahera) }\end{array}$} & \multicolumn{4}{|c|}{$\begin{array}{c}\text { Terminalia chebula } \\
\text { (Harad) }\end{array}$} & \multicolumn{4}{|c|}{ Triphala } \\
\hline & & \multicolumn{16}{|c|}{ Concentration $(\mathrm{mg} / \mathrm{ml})$} \\
\hline & \multirow{2}{*}{$\begin{array}{c}\text { Nystatin } \\
(20 \mathrm{mg} / \mathrm{ml}) 10 \mu \mathrm{l}\end{array}$} & 10 & 20 & 30 & 40 & 10 & 20 & 30 & 40 & 10 & 20 & 30 & 40 & 10 & 20 & 30 & 40 \\
\hline & & \multicolumn{16}{|c|}{ Zone of inhibition (mm) } \\
\hline C. albicans & 13 & 3.5 & 5.5 & 6.0 & 7.0 & 6.5 & 7.0 & 7.5 & 8.5 & 3.0 & 4.0 & 5.5 & 6.5 & 2.0 & 3.0 & 4.5 & 5.5 \\
\hline A. flavus & 12 & 3.0 & 4.5 & 5.0 & 6.0 & 6.0 & 6.5 & 7.0 & 8.0 & 2.5 & 3.0 & 4.5 & 5.0 & 1.5 & 2.5 & 3.5 & 4.0 \\
\hline A. niger & 13 & 5.5 & 7.5 & 8.0 & 8.5 & 7.5 & 8.0 & 8.5 & 9.0 & 3.5 & 5.0 & 6.5 & 7.5 & 3.0 & 4.5 & 5.5 & 6.0 \\
\hline
\end{tabular}


Table 3: Zone of inhibition ( $\mathrm{mm})$ by as synthesized nanoparticles using aqueous extracts of E. officinalis, T. belerica, T. chebula and Triphala at various concentrations towards different available strains of bacteria

\begin{tabular}{|c|c|c|c|c|c|c|c|c|c|c|c|c|c|c|}
\hline & & \multicolumn{13}{|c|}{ Zone of inhibition ( $\mathrm{mm})$} \\
\hline \multirow[t]{2}{*}{ Pathogens } & \multirow{2}{*}{\begin{tabular}{|c|}
$\begin{array}{c}\text { Gentamycin } \\
(10 \mu \mathrm{l})\end{array}$ \\
$(20 \mathrm{mg} / \mathrm{ml})$ \\
\end{tabular}} & \multirow{2}{*}{\begin{tabular}{|l|}
$\begin{array}{l}\text { Concen- } \\
\text { tration }\end{array}$ \\
$(\mathrm{mg} / \mathrm{ml})$ \\
\end{tabular}} & \multicolumn{3}{|c|}{$\begin{array}{c}\text { Emblica officinalis } \\
\text { (Amla) }\end{array}$} & \multicolumn{3}{|c|}{$\begin{array}{c}\text { Terminalia belerica } \\
\text { (Bahera) }\end{array}$} & \multicolumn{3}{|c|}{$\begin{array}{c}\text { Terminalia chebula } \\
\text { (Harad) }\end{array}$} & \multicolumn{3}{|c|}{ Triphala } \\
\hline & & & AgNPs & AuNPs & Ag@AuNPs & AgNPs & AuNPs & Ag@AuNPs & AgNPs & AuNPs & Ag@AuNPs & AgNPs & AuNPs & Ag@AuNPs \\
\hline $\begin{array}{c}\text { S. aureus } \\
\text { (Gram +ve) }\end{array}$ & 23 & $\begin{array}{l}10 \\
20 \\
30 \\
40\end{array}$ & $\begin{array}{l}17.0 \\
17.5 \\
19.5 \\
20.0\end{array}$ & $\begin{array}{l}16.0 \\
17.0 \\
18.0 \\
19.0\end{array}$ & $\begin{array}{l}18.0 \\
18.5 \\
20.0 \\
21.0\end{array}$ & $\begin{array}{l}13.0 \\
15.0 \\
17.5 \\
18.0\end{array}$ & $\begin{array}{l}12.0 \\
14.5 \\
15.0 \\
17.0\end{array}$ & $\begin{array}{l}14.0 \\
16.0 \\
18.0 \\
20.0\end{array}$ & $\begin{array}{l}12.5 \\
13.5 \\
15.5 \\
16.0\end{array}$ & $\begin{array}{l}11.5 \\
12.0 \\
14.0 \\
14.0\end{array}$ & $\begin{array}{l}13.5 \\
15.0 \\
17.0 \\
18.0\end{array}$ & $\begin{array}{l}16.5 \\
17.0 \\
18.0 \\
19.0\end{array}$ & $\begin{array}{l}15.0 \\
16.0 \\
16.5 \\
18.0\end{array}$ & $\begin{array}{l}17.0 \\
18.0 \\
19.0 \\
20.0\end{array}$ \\
\hline $\begin{array}{c}P . \\
\text { aeruginosa } \\
\text { (Gram-ve) }\end{array}$ & 22 & $\begin{array}{l}10 \\
20 \\
30 \\
40\end{array}$ & $\begin{array}{l}17.5 \\
18.0 \\
19.0 \\
20.0\end{array}$ & $\begin{array}{l}16.0 \\
17.5 \\
18.0 \\
19.5\end{array}$ & $\begin{array}{l}18.0 \\
19.0 \\
20.0 \\
21.0\end{array}$ & $\begin{array}{l}14.5 \\
15.0 \\
16.0 \\
19.0\end{array}$ & $\begin{array}{l}14.0 \\
14.5 \\
15.5 \\
16.0\end{array}$ & $\begin{array}{l}15.0 \\
16.0 \\
18.0 \\
20.0\end{array}$ & $\begin{array}{l}10.0 \\
13.0 \\
14.5 \\
16.0\end{array}$ & $\begin{array}{c}8.5 \\
12.5 \\
13.0 \\
14.0\end{array}$ & $\begin{array}{l}11.0 \\
14.0 \\
15.0 \\
18.0\end{array}$ & $\begin{array}{l}16.0 \\
18.0 \\
18.5 \\
19.5\end{array}$ & $\begin{array}{l}15.0 \\
17.0 \\
17.0 \\
19.0\end{array}$ & $\begin{array}{l}17.0 \\
18.5 \\
19.0 \\
20.5\end{array}$ \\
\hline $\begin{array}{c}E . \text { coli } \\
\text { (Gram -ve) }\end{array}$ & 23 & $\begin{array}{l}10 \\
20 \\
30 \\
40\end{array}$ & $\begin{array}{l}19.5 \\
20.0 \\
21.0 \\
21.5\end{array}$ & $\begin{array}{l}18.5 \\
19.5 \\
20.0 \\
20.0\end{array}$ & $\begin{array}{l}20.0 \\
21.0 \\
21.5 \\
22.0\end{array}$ & $\begin{array}{l}17.0 \\
18.5 \\
19.0 \\
19.5\end{array}$ & $\begin{array}{l}16.5 \\
17.0 \\
18.0 \\
19.0\end{array}$ & $\begin{array}{l}17.5 \\
19.0 \\
19.5 \\
20.0\end{array}$ & $\begin{array}{l}16.0 \\
17.5 \\
18.0 \\
19.5\end{array}$ & $\begin{array}{l}15.0 \\
16.0 \\
17.0 \\
18.0\end{array}$ & $\begin{array}{l}16.5 \\
18.0 \\
19.0 \\
20.0\end{array}$ & $\begin{array}{l}18.5 \\
19.0 \\
20.0 \\
20.0\end{array}$ & $\begin{array}{l}17.5 \\
18.5 \\
19.0 \\
19.5\end{array}$ & $\begin{array}{l}19.0 \\
20.0 \\
20.5 \\
21.0\end{array}$ \\
\hline $\begin{array}{c}\text { B. subtilis } \\
\text { (Gram +ve) }\end{array}$ & 23 & $\begin{array}{l}10 \\
20 \\
30 \\
40\end{array}$ & $\begin{array}{l}18.5 \\
19.5 \\
19.5 \\
20.0\end{array}$ & $\begin{array}{l}18.0 \\
19.0 \\
19.0 \\
19.5\end{array}$ & $\begin{array}{l}19.5 \\
20.0 \\
20.5 \\
21.0\end{array}$ & $\begin{array}{l}17.0 \\
17.5 \\
18.0 \\
19.0\end{array}$ & $\begin{array}{l}16.0 \\
16.5 \\
17.5 \\
18.0\end{array}$ & $\begin{array}{l}18.0 \\
19.0 \\
19.5 \\
20.0\end{array}$ & $\begin{array}{l}15.5 \\
16.5 \\
17.5 \\
20.0\end{array}$ & $\begin{array}{l}14.0 \\
16.0 \\
17.0 \\
19.0\end{array}$ & $\begin{array}{l}16.0 \\
18.0 \\
19.0 \\
21.0\end{array}$ & $\begin{array}{l}18.0 \\
19.0 \\
19.0 \\
19.5\end{array}$ & $\begin{array}{l}17.0 \\
18.0 \\
18.5 \\
18.5\end{array}$ & $\begin{array}{l}19.0 \\
19.5 \\
20.0 \\
20.0\end{array}$ \\
\hline
\end{tabular}

Table 4: Zone of inhibition (mm) by as synthesized nanoparticles using aqueous extracts of E. officinalis, T. belerica, T. chebula and Triphala at various concentrations towards different available strains of fungi

\begin{tabular}{|c|c|c|c|c|c|c|c|c|c|c|c|c|c|c|}
\hline \multirow{3}{*}{$\begin{array}{c}\text { Standard } \\
\text { Nystatin } \\
(10 \mu \mathrm{l}) \\
(20 \mathrm{mg} / \mathrm{ml})\end{array}$} & \multirow{3}{*}{\begin{tabular}{|c|}
$\begin{array}{c}\text { Fungal } \\
\text { strain }\end{array}$ \\
Pathogens \\
\end{tabular}} & \multicolumn{13}{|c|}{ Zone of inhibition ( $\mathrm{mm}$ ) } \\
\hline & & \multirow{2}{*}{\begin{tabular}{|l|}
$\begin{array}{l}\text { Concen- } \\
\text { tration }\end{array}$ \\
$(\mathrm{mg} / \mathrm{ml})$ \\
\end{tabular}} & \multicolumn{3}{|c|}{$\begin{array}{c}\text { Emblica officinalis } \\
\text { (Amla) }\end{array}$} & \multicolumn{3}{|c|}{$\begin{array}{c}\text { Terminalia belerica } \\
\text { (Bahera) }\end{array}$} & \multicolumn{3}{|c|}{$\begin{array}{c}\text { Terminalia chebula } \\
\text { (Harad) }\end{array}$} & \multicolumn{3}{|c|}{ Triphala } \\
\hline & & & AgNPs & AuNPs & Ag@AuNPs & AgNPs & AuNPs & Ag@AuNPs & AgNPs & AuNPs & Ag@AuNPs & AgNPs & AuNPs & Ag@AuNPs \\
\hline 13 & C. albicans & $\begin{array}{l}10 \\
20 \\
30 \\
40\end{array}$ & $\begin{array}{l}6.5 \\
7.5 \\
8.0 \\
9.0\end{array}$ & $\begin{array}{r}7.0 \\
9.0 \\
9.5 \\
10.5\end{array}$ & $\begin{array}{r}8.0 \\
9.5 \\
10.5 \\
11.0\end{array}$ & $\begin{array}{r}7.5 \\
8.0 \\
9.0 \\
10.0\end{array}$ & $\begin{array}{r}8.0 \\
10.0 \\
10.5 \\
11.5\end{array}$ & $\begin{array}{r}9.5 \\
10.5 \\
11.0 \\
12.0\end{array}$ & $\begin{array}{l}5.5 \\
6.0 \\
6.5 \\
8.0\end{array}$ & $\begin{array}{r}6.0 \\
7.0 \\
8.0 \\
10.0\end{array}$ & $\begin{array}{r}6.5 \\
7.5 \\
9.0 \\
10.5\end{array}$ & $\begin{array}{l}4.0 \\
5.0 \\
6.0 \\
8.5\end{array}$ & $\begin{array}{l}5.0 \\
6.0 \\
7.5 \\
9.5\end{array}$ & $\begin{array}{r}5.5 \\
6.5 \\
8.0 \\
10.0\end{array}$ \\
\hline 12 & A. flavus & $\begin{array}{l}10 \\
20 \\
30 \\
40\end{array}$ & $\begin{array}{l}5.0 \\
5.5 \\
7.5 \\
8.0\end{array}$ & $\begin{array}{l}6.5 \\
8.0 \\
8.5 \\
9.0\end{array}$ & $\begin{array}{r}7.0 \\
8.5 \\
9.5 \\
10.0\end{array}$ & $\begin{array}{r}7.0 \\
8.0 \\
9.5 \\
10.0\end{array}$ & $\begin{array}{r}8.5 \\
9.5 \\
10.0 \\
10.5\end{array}$ & $\begin{array}{r}9.0 \\
10.0 \\
10.5 \\
11.0\end{array}$ & $\begin{array}{l}4.0 \\
5.0 \\
6.0 \\
7.0\end{array}$ & $\begin{array}{l}6.0 \\
7.0 \\
7.5 \\
8.5\end{array}$ & $\begin{array}{l}7.0 \\
8.0 \\
8.5 \\
9.0\end{array}$ & $\begin{array}{l}4.5 \\
5.0 \\
5.5 \\
6.0\end{array}$ & $\begin{array}{l}5.5 \\
6.0 \\
6.5 \\
8.0\end{array}$ & $\begin{array}{l}6.0 \\
7.5 \\
8.0 \\
8.5\end{array}$ \\
\hline 13 & A. niger & $\begin{array}{l}10 \\
20 \\
30 \\
40\end{array}$ & $\begin{array}{l}7.0 \\
8.5 \\
9.0 \\
9.5\end{array}$ & $\begin{array}{r}8.0 \\
10.0 \\
10.5 \\
11.5\end{array}$ & $\begin{array}{r}9.0 \\
10.5 \\
11.0 \\
12.0\end{array}$ & $\begin{array}{r}8.5 \\
9.0 \\
9.5 \\
10.0\end{array}$ & $\begin{array}{r}9.0 \\
10.0 \\
11.0 \\
11.5\end{array}$ & $\begin{array}{l}10.0 \\
11.0 \\
11.5 \\
12.5\end{array}$ & $\begin{array}{l}6.0 \\
6.5 \\
7.0 \\
9.0\end{array}$ & $\begin{array}{r}7.5 \\
8.0 \\
8.5 \\
10.0\end{array}$ & $\begin{array}{r}8.5 \\
9.0 \\
10.5 \\
11.0\end{array}$ & $\begin{array}{l}4.5 \\
5.0 \\
6.0 \\
8.0\end{array}$ & $\begin{array}{l}6.0 \\
6.5 \\
8.0 \\
9.0\end{array}$ & $\begin{array}{r}7.0 \\
8.0 \\
9.5 \\
10.5\end{array}$ \\
\hline
\end{tabular}




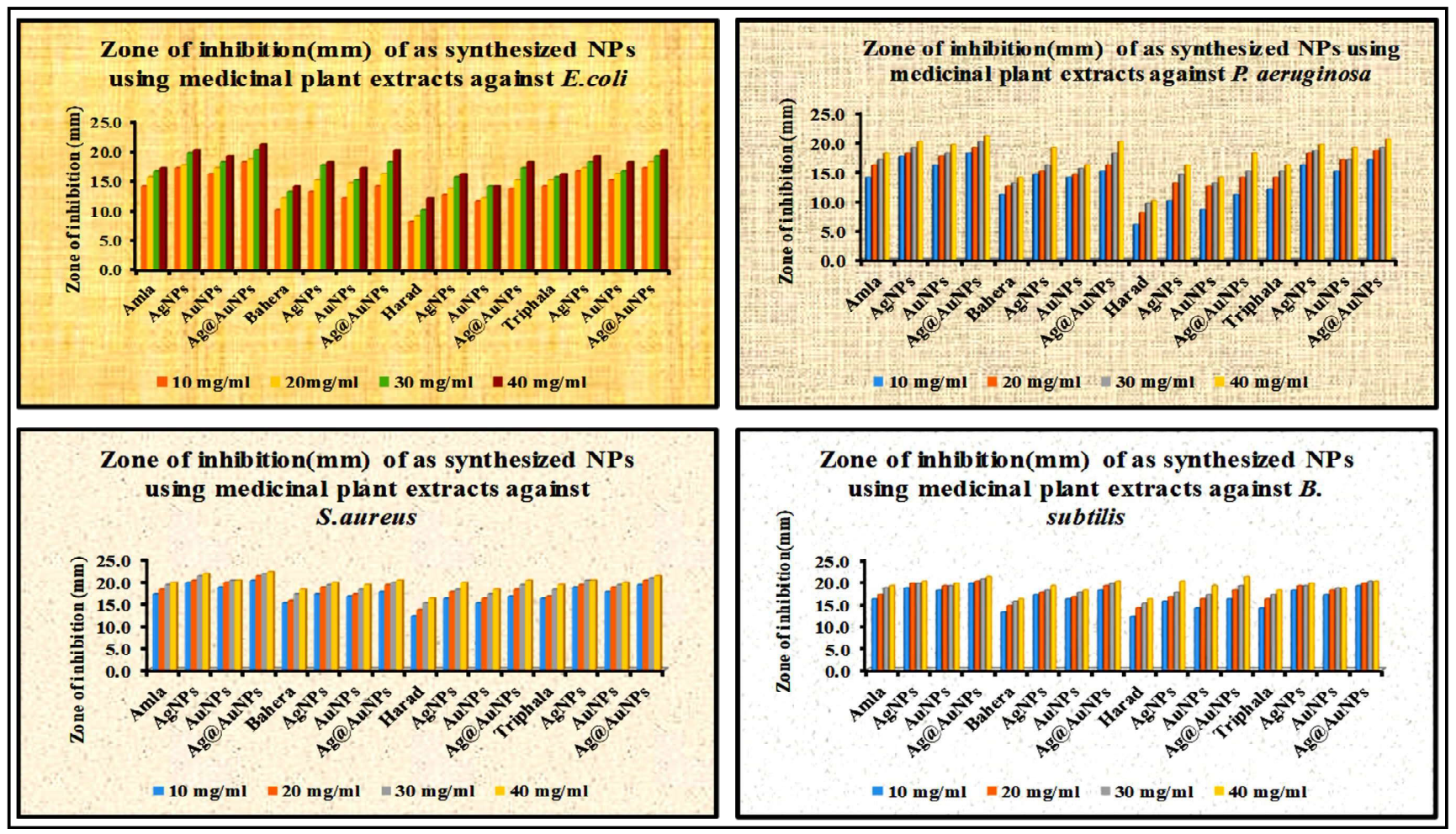

Figure 1: Zone of inhibition (mm) of as synthesized NPs using medicinal plant extracts against the test organisms (E. coli, P. aeruginosa, S. aureus and B. subtilis).

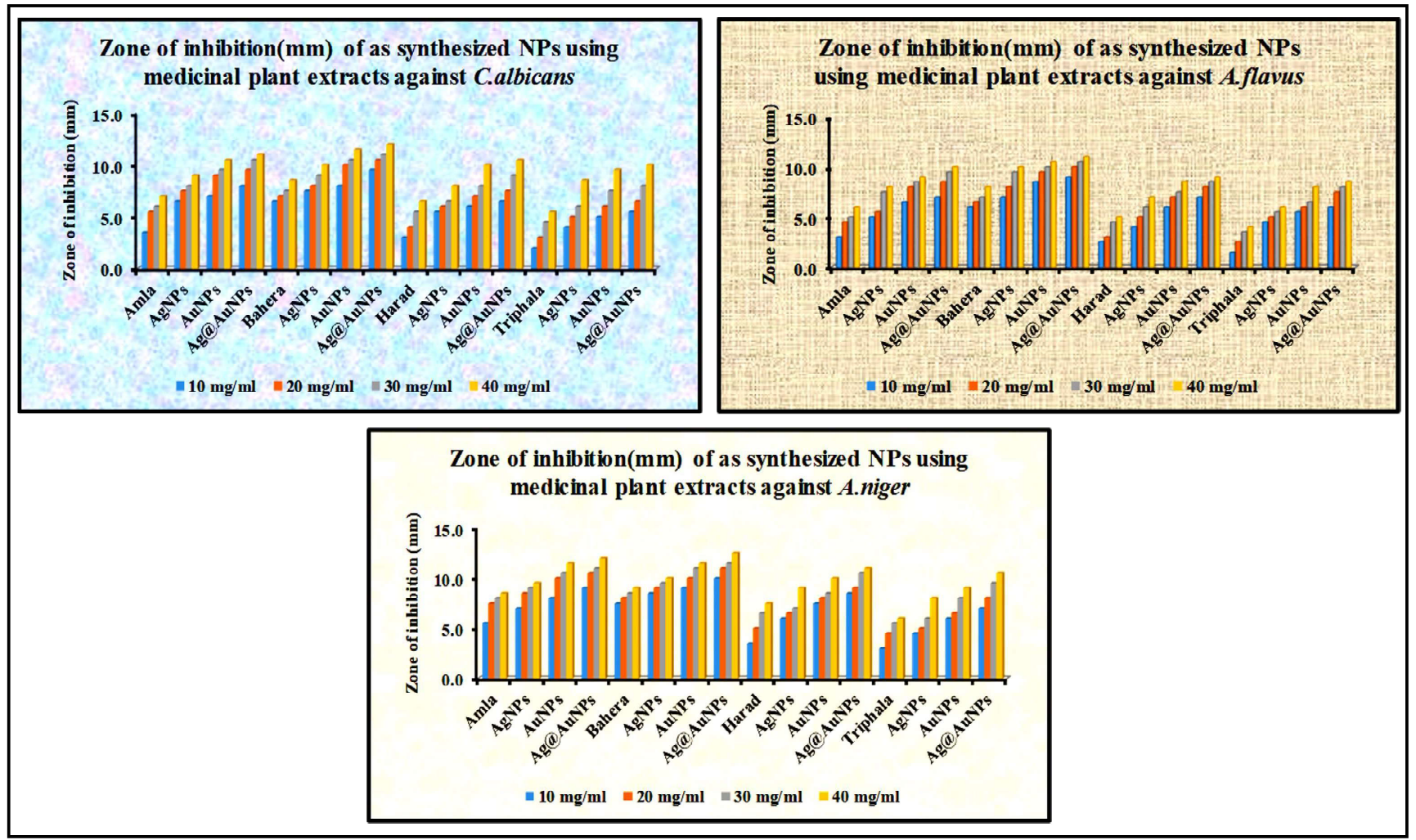

Figure 2: Zone of inhibition (mm) of as synthesized NPs using medicinal plant extracts against the test organisms (C. albicans, A. flavus and A. niger). 


\section{Discussion}

Green synthesis of AgNPs, AuNPs and bimetallic nanoparticles by using plant extracts gained significant interest over the years due to the remarkable antimicrobial properties of these nanoparticles. The high surface area-to-volume ratio is the main reason behind the excellent antimicrobial activity of metallic nanoparticles, which enables greater presence of atoms on the surface and, in turn, larger contact with the environment. In addition to this, these Nano sized particles penetrate easily through cell membrane, interact with intracellular materials and finally resulting in cell destruction in the process of multiplication.

The smaller nanoparticles have higher antibacterial activity because of more surface exposure to the bacterial membrane (Pal et al., 2007; Rai et al., 2012). The positive charge of $\mathrm{Ag}^{+}$interacts with the negative charge on the cell wall of bacteria which leads to changes in morphology of cell wall and increase in the cell permeability or leakage of the cell which consequently results in necrobiosis (Dibrov et al., 2002; Patil et al., 2012).

The greater affinity of AgNPs to interact with phosphorous and, sulfur-containing biomolecules present in extracellular (membrane protein), and intracellular components (DNA bases, protein); makes these biomolecules affect cellular division, respiration, and ultimately, the survival of the cell. According to other investigations, the $\mathrm{Ag}^{+}$has an affinity for nitrogen and sulfur, can inhibit and disrupt protein structures by binding to thiol and amino groups (Choi et al., 2008). The interaction of nanoparticles with thiol group could also be liable for the induction of reactive oxygen species (ROS), which results in the inhibition of respiratory enzymes and, consequently, death (Holt and Brad 2005; Ninganagouda et al., 2014). Silver ions acting as an antibacterial agent interacts with the peptidoglycan cell wall and plasma membrane (Radzig et al., 2013) and also prevent bacterial DNA replication by interfering with sulfhydryl groups in protein (Seth et al., 2011).

The higher antimicrobial activity of nanoparticles is particle size dependent, which permits greater surface contact and an immediate interaction with the membranes of pathogenic microorganisms. The antibacterial activities of metallic nanoparticles were found to be associated to their shapes and sizes. Nanoparticles having size smaller than $10 \mathrm{~nm}$ interact with bacteria and thus produce electronic effects, thereby improving the reactivity of nanoparticles. Thus, it proves that the bactericidal effect of nanoparticles is size dependent.

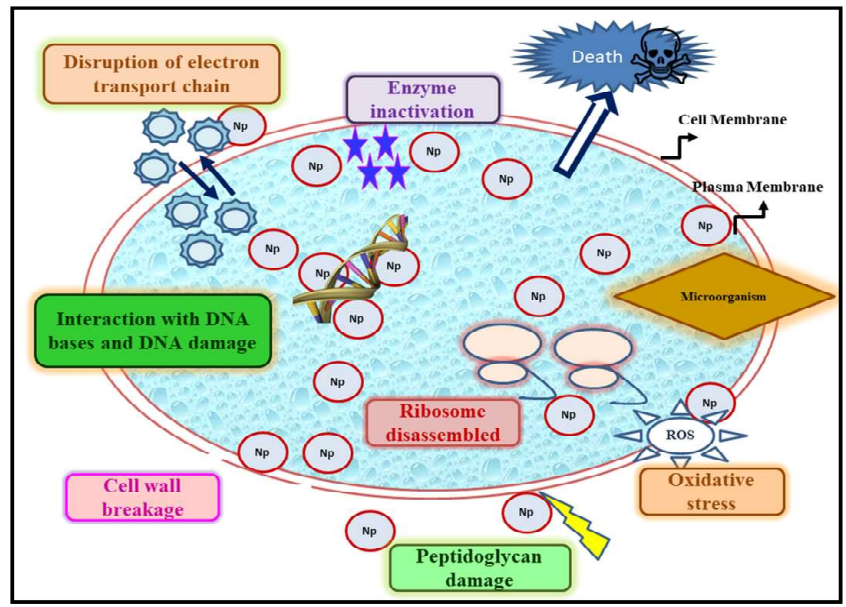

Figure 3: Diagrammatic representation of mode of action of AgNPs for antibacterial activity.
The cell membranes of the microorganisms (bacteria/fungi) interact with the media, so metallic NPs will have some interactions for releasing metal ions which interfere with the following processes such as DNA replication, cell membrane formation, cell division, and so forth, of certain microorganisms such as bacteria, which results in an antimicrobial effect (Morones et al., 2005; Souli et al., 2012).

The nanoparticles get attached to the surface of cell membrane disturbing the permeability and respiration function of the cell (Rai et al., 2009; Sharma et al., 2009). The interaction of nanoparticles with sulfur or phosphorus-containing biomolecules in the cell such as DNA causes damage to the cell. Therefore, sulfur-containing proteins in the membrane or inside cells and phosphorus containing elements like DNA are likely to be preferential sites for binding Ag in the nanoparticles.

The bacterial DNA tends to lose its ability to replicate, when bacteria are treated with AgNPs. Lokina et al., (2013) showed that AgNPs could destabilize the outer membrane and rupture the plasma membrane, thereby depleting intracellular ATP.

Figure 3 shows the mechanisms which can be observed since, there are multiple targets for the antibacterial agents, viz., (a) inhibiting protein biosynthesis by targeting bacterial ribosomes; (b) bacterial cell-wall biosynthesis by targeting the interaction of peptide and enzymes; (c) bacterial cell membrane destruction by structural alteration; (d) bacterial DNA replication and repair by targeting DNA Gyrase, and (e) inhibition of a metabolic pathway, i.e., reprogramming the targeted structure.

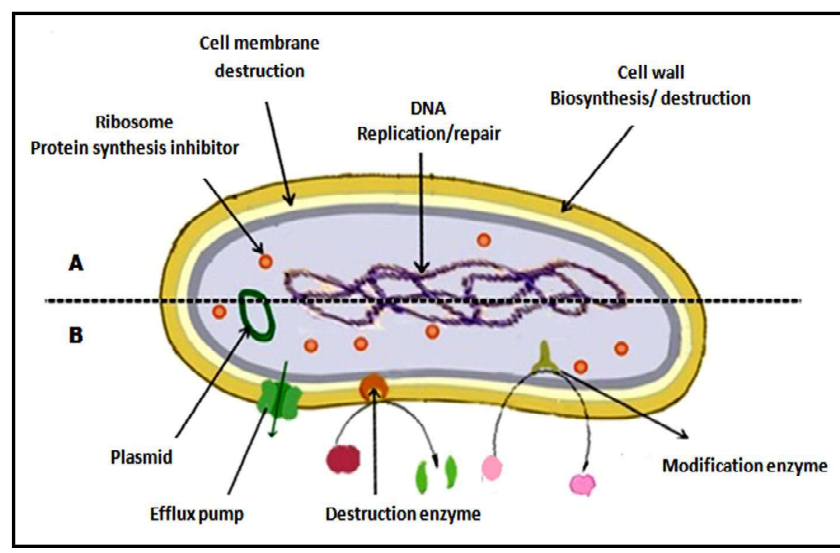

Figure 4: Available Targets for Antibacterial Agents (A) Antibacterial agents resistance mechanism in bacteria (B).

Further, under normal circumstances, ROS damage can be controlled with antioxidant enzymes present in the cell. However, when the nanoparticles are present inside the cell, the nanoparticles could restrain the antioxidative enzymes to inhibit the defending capability against ROS damage. It is also reported that the nanoparticles break and disturb the balance of oxidant/antioxidant and generate the accumulation of ROS in bacteria. However, A further study is needed to explore the exact mechanism of AgNPs on different bacterial cells.

Priester et al. (2009) suggested that the action mechanism of the metallic NPs involves the interaction of enzymes and damage in the DNA caused by-SH groups and therefore oxidative stress generation (Zain et al., 2014; Santo et al., 2012; Ren et al., 2009). 
According to the studies suggested, when metallic nanoparticles interact with bacteria, a number of changes take place in the cell membrane's morphology which results in a significant increase in the permeability, thus affecting proper transport through the plasma membrane (Auffan et al., 2009; Brayner et al., 2006), leaving the bacterial cells incapable of properly regulating transport through the plasma membrane, which results into cell death. It is also believed that micro-organisms carry a negative charge while metallic nanoparticles carry a positive charge. This creates an "electromagnetic" attraction between the microbe and treated surface (Rezaei et al., 2010).

Luo et al. (2011) documented that the nanoparticles induce oxidative stress to bacteria is induced by the presence of metallic/bimetallic nanoparticles and results in the ROS production. For example, the antibacterial activity could be explained based on the following reactive oxygen species (ROS) such as $\mathrm{H}_{2} \mathrm{O}_{2}$, hydroxyl radicals, singlet oxygen, and $\mathrm{M}^{\mathrm{n}+}$ ions, which are released on the surface that cause stern damage to bacteria (Jan et al., 2014; Huh and Kwon 2011; Feris et al., 2010). The generation of hydrogen peroxide $\left(\mathrm{H}_{2} \mathrm{O}_{2}\right)$ from the surface of metal salt was proved to be an effective method for the inhibition of bacterial growth according to some studies (Yamamoto, 2001). It has been reported that both UV and visible light can activate metallic nanoparticles and consequently, electron-hole pairs $\left(\mathrm{e}^{-} / \mathrm{h}^{+}\right)$can be created. The generation of $\mathrm{H}_{2} \mathrm{O}_{2}$ can be explained as follows: the holes generated, split the $\mathrm{H}_{2} \mathrm{O}$ molecule from the suspension of nanoparticles into $\mathrm{OH}^{-}$and $\mathrm{H}^{+}$. Furthermore, dissolved oxygen molecules are converted to superoxide radical anions $\left(\mathrm{O}_{2}{ }^{-}\right)$which react with hydrogen ion $\left(\mathrm{H}^{+}\right)$ to produce $\mathrm{HO}_{2}{ }^{-}$radicals. The collision of these hydroxyl radicals with electrons will produce hydrogen peroxide anions $\mathrm{HO}_{2}^{-}$, which react with hydrogen to generate $\mathrm{H}_{2} \mathrm{O}_{2}$ molecules (Figure 5). Therefore, the $\mathrm{H}_{2} \mathrm{O}_{2}$ molecules generated can penetrate inside the cell membrane and kill the bacteria (Padmavathy and Vijayaraghavan 2008; Shah et al., 2014). The $\mathrm{e}^{-} / \mathrm{h}^{+}$pair recombination minimizes the chances of ROS generation. Lattice defects play an important role in the inhibiting $\mathrm{e}^{-} / \mathrm{h}^{+}$pair recombination process (Yildirim et al., 2013). These defects may act as trapping centers and inhibit photo induced $\mathrm{e}^{\mathrm{e} / \mathrm{h}^{+}}$pair recombination (Zhao et al., 2011) resulting in greater antibacterial activity.

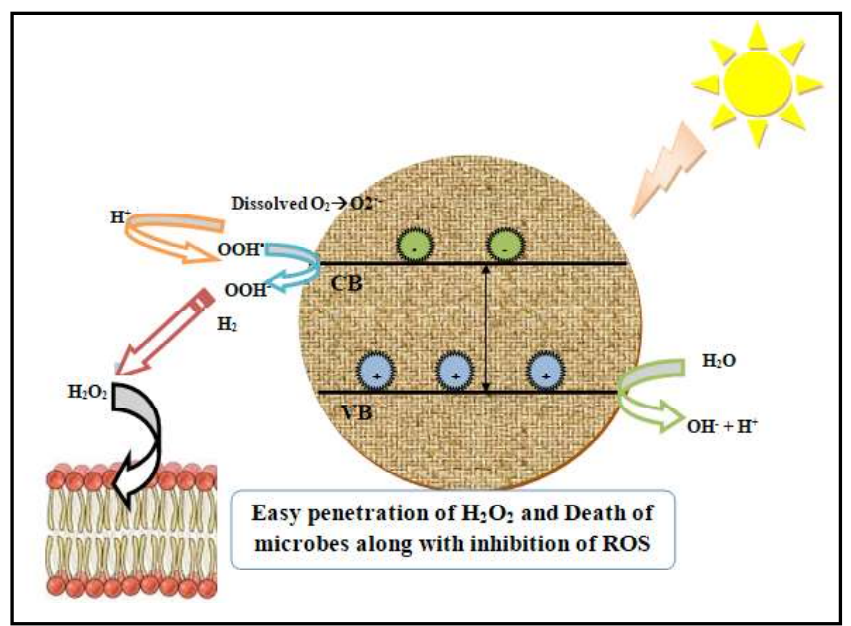

Figure 5: Diagrammatic representation of mechanisms of action of AgNPs for antibacterial activity.
The only major negative aspect of eco-friendly process by using plant extract to synthesize nanoparticles for commercially viable products is the anisotropic particle formation; plant extract contains more than one reducing agent (antioxidants/secondary metabolites) which produces different size and shape of nanoparticles. The specific compound from plant extract involved in the synthesis of nanoparticles remains indistinct. There is a need to find the precise component of the plant extract responsible for the reduction and stabilization of synthesized nanoparticles.

Future outlook of plant-mediated nanoparticles synthesis includes an extension of laboratory-based work to industrial scale, the revelation of phytochemicals involved in the synthesis of nanoparticles using bioinformatics tools and deriving the exact mechanism involved in inhibition of pathogenic microorganisms.

\section{Conclusion}

The sign of biochemical properties of as synthesized nanoparticles establishes a ground to bring its effective use as one or together, against different pathological conditions. Thus, results obtained could also provide some helpful justifications to formulate these fruit extract in the modern health care system. This kind of study may also make a possible platform in future for preparing Nanomedicine for fungal and bacterial-related diseases. In our future studies, the synthesized nanoparticles are going to be applied along with food preservative agents so as to organize the antimicrobial packaging system to increase the merchandise time period and maintain food safety by reducing the expansion rate of micro-organisms. It is confirmed that AuNPs and AgNPs are capable of rendering high antifungal and antibacterial efficacy respectively and hence features a great potential in the preparation of drugs used against microbial diseases. Synergistic effects of two metals in bimetallic NPs carry out certain functions which were otherwise not possible with monometallic nanoparticles alone. Bimetallic nanoparticles are of great interest as they hold varieties of applications in the field of nano-medicine, for drug delivery, as catalysts, as antimicrobial, in bio-sensing, in overcoming environmental pollution. Improved bimetallic nanoparticles development will surely prove to be a boon to the modern society.

\section{Acknowledgments}

We would like to thank CSIR, New Delhi for funding and supporting this research and IIT Delhi for providing the necessary facilities during the experimental investigation.

\section{Conflict of interest}

The authors declare that there are no conflicts of interest in the course of conducting the research. Both the authors had final decision regarding the manuscript and decision to submit the findings for publication.

\section{References}

Auffan, M.; Rose, J.; Bottero, J.; Lowry, G.; Jolivet, J. P. and Wiesner, M. (2009). Towards a definition of inorganic nanoparticles from an environmental, health and safety perspective. Nat. Nanotech., 4:634-641.

Bhandari, P. and Kamdod, M. (2012). Emblica officinalis (Amla): A review of potential therapeutic applications. Int. J. Green Pharm., 6:257-269.

Brayner, R.; Ferrari-Iliou, R.; Brivois, N.; Djediat, S.; Benedetti, M. and Fiévet, F. (2006). Toxicological impact studies based on Escherichia coli bacteria in ultrafine $\mathrm{ZnO}$ nanoparticles colloidal medium. Nano Letters, 6:866-870. 
Choi, O.; Deng. K.; Kim, N.; Ross, L.; Surampalli, R. and Hu, Z. (2008). The inhibitory effect of silver nanoparticles, silver ions and silver chloride colloids on microbial growth. Water Res. 42:3066-3074.

Dibrov, P.; Dzioba. J.; Gosink, K. and Hase, C. (2002). Chemiosmotic mechanism of antimicrobial activity of $\mathrm{Ag}^{+}$in Vibrio cholerae. Antimicrob. Agents Chemother., 46:2668-2670.

Feris, K.; Otto, C.; Tinker, J.; Wingett, D.; Punnoose, A. and Thurber, A. (2010). Electrostatic interactions affect nanoparticle-mediated toxicity to gram-negative bacterium Pseudomonas aeruginosa PAO1. Langmuir., 26:4429-4436.

Holt, K. and Brad, A. (2005). Interaction of silver (I) ions with the respiratory chain of Escherichia coli: An electrochemical and scanning electrochemical microscopy study of the antimicrobial mechanism of micromolar $\mathrm{Ag}^{+}$. Biochemist., 44:13214-13223.

Huh, A. and Kwon, Y. (2011). "Nanoantibiotics": A new paradigm for treating infectious diseases using nanomaterials in the antibiotics resistant era. J. Cont. Rel., 156:128-145.

Jan, T.; Iqbal, J.; Ismail, M. and Mahmood, A. (2014). Synthesis of highly efficient antibacterial agent Ag doped ZnO nanorods: Structural, raman and optical properties. J. Appl. Phy., 115:154308.

Khameneh, B.; Iranshahy, M. and Soheili, V. (2019). Review on plant antimicrobials: A mechanistic viewpoint. Antimicrob. Resist. Infect. Control, 8:118.

Lokina, S. and Narayanan, V. (2013). Antimicrobial and anticancer activity of gold nanoparticles synthesized from grapes fruit extract. Chem. Sci. Trans., 2:S105-S10.

Luo, Z.; Wu. Q.; Zhang. M.; Li, P. and Ding, Y. (2011). Cooperative antimicrobial activity of CdTe quantum dots with rocephin and fluorescence monitoring for Escherichia coli. Jour. of Col. and Inter. Science, 362:100-106.

Mahady, G. B. (2005). Medicinal plants for the prevention and treatment of bacterial infections. Curr. Pharm. Des., 11:2405-2427.

Morones, J.; Elechiguerra, J.; Camacho, A.; Holt, K.; Kouri, J. and Ramírez, J. (2005). The bactericidal effect of silver nanoparticles. Nanotech., 16:2346-2353.

Ninganagouda, S.; Rathod, V.; Singh. D.; Hiremath, J.; Singh, A., Mathew, J. and Ul-Haq, M. (2014). Growth kinetics and mechanistic action of reactive oxygen species released by silver nanoparticles from Aspergillus niger on Escherichia coli. Biomed. Res. Int.

Padmavathy, N. and Vijayaraghavan, R. (2008). Enhanced bioactivity of ZnO nanoparticles: An antimicrobial study. Sci. and Tech. of Advanc. Mater., 9:035004.

Pal, S.; Tak, Y. and Song, J. (2007). Does the antibacterial activity of silver nanoparticles depend on the shape of the nanoparticles? A study of the gram-negative bacterium Escherichia coli. Appl. Environ. Microbiol., 73:1712-1720.

Patil, S.; Borase, H.; Patil, C. and Salunke, B. (2012). Biosynthesis of silver nanoparticles using latex from few euphorbian plants and their antimicrobial potential. Appl. Biochem. Biotech., 167:776-790.
Priester, J.; Stoimenov, P.; Mielke, R.; Webb, S.; Ehrhardt, C. and Zhang, J. (2009). Effects of soluble cadmium salts versus CdSe quantum dots on the growth of planktonic Pseudomonas aeruginosa. Environ. Sci. and Tech., 43(7):2589-2594.

Radzig, M.; Nadtochenko, V.; Koksharova, O.; Kiwi. J.; Lipasova, V. and Khmel, I. (2013). Antibacterial effect of silver nanoparticles on gram negative bacteria: Influence on the growth and biofilms formation, mechanism of action. Colloids. Surf. B. Bioint., 102:300-306.

Rai, M.; Yadav, A. and Gade, A. (2009). Silver nanoparticles as a new generation of antimicrobials. Biotech. Advanc., 27:76-83.

Rai, M.; Deshmukh, S.; Ingle, A. and Gade, A. (2012). Silver nanoparticles: The powerful nanoweapon against multidrug-resistant bacteria. J. Appl. Microbiol., 112:841-852.

Ren, G.; Hu, D.; Cheng, E.; Vargas-Reus, M.; Reip, P. and Allaker, R. P. (2009). Characterisation of copper oxide nanoparticles for antimicrobial applications. Int. J. Antimicro. Agent, 33:587-590.

Rezaei-Zarchi S.; Javed, A.; Javeed Ghani, M.; Soufian, S.; Barzegari, Firouzabadi, F. and Bayanduri Moghaddam A. (2010). Comparative study of antimicrobial activities of $\mathrm{TiO}_{2}$ and $\mathrm{CdO}$ nanoparticles against the pathogenic strain of Escherichia coli. Iranian Journal of Pathology; 5(2):83-89.

Santo, C.; Quaranta, D. and Grass, G. (2012). Antimicrobial metallic copper surfaces kill Staphylococcus haemolyticusvia membrane damage. Microbiol. Open., 1:46-52.

Seth, D.; Choudhury, S.; Pradhan, S.; Gupta, S.; Palit, D.; Das, S.; Debnath, N. and Goswami, A. (2011). Nature inspired novel drug design paradigm using nanosilver: Efficacy on multi-drug-resistant clinical isolates of tuberculosis. Curr. Microbiol., 62:715-726.

Shah, M.; Fawcett, D.; Sharma, S.; Tripathy, S. and Poinern, G. (2015). Green synthesis of metallic nanoparticles, via, biological entities. Materials, 8:7278-7308

Sharma, V.; Yngard, R. and Lin, Y. (2009). Silver nanoparticles: Green synthesis and their antimicrobial activities. Advanc. Coll. and Inter. Sci., 145:83-96.

Souli, M.; Galani, I.; Plachouras, D.; Panagea, T.; Armaganidis, A. and Petrikkos, G. (2012). Antimicrobial activity of copper surfaces against carbapenemase-producing contemporary Gram-negative clinical isolates. J. Anti. Chemo., 68:852-857.

Yamamoto, O. (2001). Influence of particle size on the antibacterial activity of zinc oxide. Int. J. Inorg. Mater., 3:643-646.

Yýldýrým, Ö.; Unalan, H. and Durucan, C. (2013). Highly efficient room temperature synthesis of silver-doped zinc oxide (ZnO:Ag) nanoparticles: Structural, optical, and photocatalytic properties. J. Am. Cera. Soc., 96:766-773.

Zain, N.; Stapley, A. and Shama, G. (2014). Green synthesis of silver and copper nanoparticles using ascorbic acid and chitosan for antimicrobial applications. Carbo. Pol., 112:195-202.

Zhao, J.; Wang, L.; Yan, X.; Yang, Y.; Lei, Y. and Zhou, J. (2011). Structure and photocatalytic activity of Ni-doped ZnO nanorods. Mat. Res. Bull., 46:1207-1210.

Citation: Tamanna Malik and V. K. Madan (2020). Enhanced antimicrobial activity of as synthesized nanoparticles using natural antioxidants of plants origin. Ann. Phytomed., 9(1):199-206. http://dx.doi.org/10.21276/ap.2020.9.1.26 